\title{
地球規模における大気中 $\mathrm{CO}_{2}$ 濃度の 時空間変動及び空間分布特性
}

\author{
THE SPATIOTEMPORAL FLUCTUATION AND SPATIAL DISTRIBUTION \\ CHARACTERISTICS IN ATMOSPHERIC CO2 CONCENTRATION \\ ON A GLOBAL SCALE
}

\author{
清水 保 $^{1}$ ・長谷部 正彦 ${ }^{2} \cdot$ 鈴木 善晴 $^{3}$ - 日野 幹雄 ${ }^{4}$ \\ Tamotsu SHIMIZU, Masahiko HASEBE, Yoshiharu SUZUKI and Mikio HINO \\ 1学生会員 宇都宮大学院 工学研究科エネルギー環境科学専攻 ( T 321-8585 宇都宮市陽東 7-1-2) \\ 2 正会員 工博 宇都宮大学教授 工学部建設学科建設工学講座 (T321-8585 宇都宮市陽東 7-1-2) \\ ${ }^{3}$ 正会員 工修 宇都宮大学助手 工学部建設学科建設工学講座 ( T 321-8585 宇都宮市陽東 7-1-2) \\ ${ }^{4}$ 正会員 工博 (广 251-0033 神奈川県藤沢市片瀬山 4-20-6)
}

\begin{abstract}
In recent years, global warming is progressing and increasing $\mathrm{CO} 2$ concentration in the atmosphere is generally its major cause. Accordingly many researchers of various fields have been carried out on $\mathrm{CO} 2$. But there are many uncertainties on $\mathrm{CO} 2$. We considered that it is necessary to make a precise model to clarify these uncertainties. So we thought that it was significant to grasp the variation characteristics of atmospheric $\mathrm{CO} 2$ concentration.

Then, in this paper we investigated to grasp the fluctuation characteristics of atmospheric $\mathrm{CO} 2$ concentration, such as the spatiotemporal fluctuation and spatial distribution characteristics, by using the atmospheric $\mathrm{CO} 2$ concentration practical data that has been equipped in recent years. Moreover we confirmed how much influence the Mt. Pinatubo Eruption would have had on the atmospheric $\mathrm{CO} 2$ concentration fluctuation because it has not been clarified.
\end{abstract}

Key Words : atmospheric CO2 concentration, time and space fluctuation and spatial distribution characteristics, continuous wavelet analysis, spatiotemporal

\section{1.はじめに}

産業革命以降の工業等の発展に伴い, 大気中の $\mathrm{CO}_{2}$ 濃度が次第に増加していった。ここ最近, $\mathrm{CO}_{2}$ 濃度は 人間活動の活発化により急激に増加しており, 今後地 球温暖化は深刻化していくことがほぼ確実であり, 様々 な気候変動を引き起こしていくと報告されている1). そ のために, 地球温暖化の適切な対策が早急に求められ ている. $\mathrm{CO}_{2}$ の研究として, 従来は $\mathrm{CO}_{2}$ 濃度のデータ が充実していなかったため, 大気輸送モデルやインバー スモデル等を用いた研究が数多く行われてきた2). しか し，これらのモデルによる解析結果にばらつきが見ら れる. 本解析では, このばらつきは $\mathrm{CO}_{2}$ 濃度の変動特 性を考慮していないからであると考え, 変動特性を考 慮した有意なモデルを構築することができれば，未だ 解明されていない Sink and Source 等の解明につなが ると考えた. 同時に, 様々なイベント（1991 年ピナツ ボ山の噴火やエルニーニョ現象等）が $\mathrm{CO}_{2}$ 濃度に影響 を与えていると報告されている3)が，その影響は未だ明
確には示されていないと思われる. そこで本研究は, 近 年充実してきた実測データを基に大気中 $\mathrm{CO}_{2}$ 濃度の時 空間変動及び空間分布特性を把握し, 様々なイベント に着目し，これらが与えている影響を明確に示すこと を目的としている.

\section{2. 解析地点}

本研究では, WDCGG（温室効果ガス世界資料セン ター）によって収集された大気中 $\mathrm{CO}_{2}$ 濃度の月平均実 測データ（CD-ROM）を用いた。これらには，

- IN SITU : 現場で継続的に測定

- Flask Sampling : 現場でサンプリングしたも のを研究所等に持ち帰り測定

の二通りの手法で測定されたデータが混じっているが, 両手法で測定された 7 地点で検討を行った結果, 表-1 にあるように双方に大きな相違がなかったため，本解 
表-1 両手法での測定データの相関係数

\begin{tabular}{|l|c|c|}
\hline Station & Latitude & C.C.(common term) \\
\hline \hline Alert & $82^{\circ} 27^{\prime} \mathrm{N}$ & $0.9880(1985-1992)$ \\
\hline Zeppelinfjellet & $78^{\circ} 54^{\prime} \mathrm{N}$ & $0.9757(1994-1999)$ \\
\hline Barrow & $71^{\circ} 19^{\prime} \mathrm{N}$ & $0.9979(1973-2001)$ \\
\hline Mauna Loa & $19^{\circ} 32^{\prime} \mathrm{N}$ & $0.9993(1976-2001)$ \\
\hline Tutuila & $14^{\circ} 15^{\prime} \mathrm{S}$ & $0.9995(1979-2001)$ \\
\hline Amsterdam Island & $37^{\circ} 48^{\prime} \mathrm{S}$ & $0.9966(1982-1990)$ \\
\hline South Pole & $89^{\circ} 59^{\prime} \mathrm{S}$ & $0.9995(1983-2000)$ \\
\hline
\end{tabular}

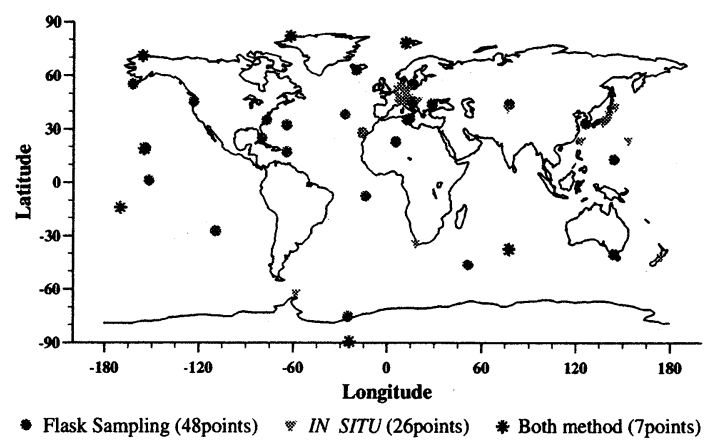

図-1 解析地点（全 81 地点）

析ではこれらの解析地点を合わせた 95 地点を解析に用 いた．本論文で用いたデータには久損があるものがあ るため, 最小二乗法により求めた回帰直線とフーリエ 級数を用いて内挿を行った. データの存在期間として は, ある程度の期間を有するものを用いているため, 短 いもので約 10 年程度, 長いものでは 34 年間となって いる. また, 全解析地点（95 地点）の中には, 緯度は 分かるものの経度が記されていない「Mobile」と属さ れたものがあるが，空間分布図など空間的な広がりを 見る場合には, この Mobile データは除いた，図-1には Mobileの解析地点を除いた 81 地点を示した.

\section{3. 解析方法}

\section{(1) 時系列解析}

一般に時系列は，傾向成分 (trend component)，周期 成分 (periodic component), 確率変動成分 (stochastic component）の 3 成分から構成されている. ある時系 列（原系列）を $y_{t}$ とすれば式 (1) となる.

$$
y_{t}=T_{t}+P_{t}+\xi_{t}
$$

ここに, $T_{t}$ : 傾向成分, $P_{t}$ : 周期成分, $\xi_{t}$ : 確率 変動成分である. $T_{t}$ は最小二乗法, $P_{t}$ はフーリ工級 数を用い決定する. これにより, 原系列から傾向成分, 周期成分を除くことで非決定論的成分である $\xi_{t}$ を決定 するが, 本解析では主に傾向成分と周期成分について 解析を行ったので，本論文では扱っていない.

\section{(2) スペクトル解析}

各解析地点において, FFTにより式(2)を用いてパ ワースペクトル $P(f)$ (two-sided spectrum) を求め, 周 期を定量的に求めた. また, そこで得た卓越した周波 数やそのパワースペクトルの違いを分布させることで, 地球全体に打ける変動の違いの把握を試みた.

$$
P(f)=\lim _{T \rightarrow \infty}\left[\frac{1}{T} F(f) F^{*}(f)\right]
$$

ここに, $T:$ 定義域, $F(f):$ フーリエ成分である.

\section{(3) 連続ウェーブレット解析 ${ }^{4)}$}

式 (3) のような連続ウェーブレット変換 $T(a, b)$ によ り，ある周波数成分の振幅変動を時間的に捉えること で，その周波数成分が見かけ上の周期なのか, 実際の 長期的な周期なのかを明らかにしようと試みた.

$$
\begin{gathered}
T(a, b)=\frac{1}{\sqrt{c_{\phi}}} \int_{-\infty}^{\infty} \varphi^{(a, b)}(t) f(t) d t \\
\varphi^{(a, b)}(t)=\frac{1}{\sqrt{|a|}} \varphi\left(\frac{t-b}{a}\right)
\end{gathered}
$$

ここに, $\varphi^{(a, b)}(t)$ : ウェーブレット関数, $a$ : 周波数に 相当するパラメータ, $b:$ 時間パラメータ, $\varphi(t):$ アナ ライジングウェーブレット, $c_{\phi}$ :アナライジングウェー ブレットのフーリエ変換で定義される有限值の定数で ある。

連続ウェーブレット解析はアナライジングウェーブ レットにより結果が変わるため, 離散ウェーブレットを 用いた方が良いが，データ数が 2 のべき乗でなくては ならなく, $\mathrm{CO}_{2}$ 濃度変動は 12 ケ月周期を持っているの で, データを加工する必要がある. そのため, データ を加工せずに使える連続ウェーブレット解析を行った.

幾つかのアナライジングウェーブレットで検討を行つ た結果, 最適だと思われる, 式 (5) で表されるメキシ カンハットを用いた。

$$
\varphi(t)=\left(1-t^{2}\right) \exp \left(-\frac{t^{2}}{2}\right)
$$

本論文では，原系列から傾向成分と 1 年以下の周期 成分を除いたもの（残差成分）について各地点で連続 ウェーブレット解析を行った. これにより，局所的な周 波数成分が時間とともにどのように変化しているかを 示すことで, $\mathrm{CO}_{2}$ 濃度の周期特性の把握を試みた.

\section{(4) 相関行列}

地点毎の $\mathrm{CO}_{2}$ 濃度変動の相関関係を見るために, 19941998 年の同時期における各解析地点同士の相関係数を 基に相関行列で表した. ある 2 地点の $\mathrm{CO}_{2}$ 濃度月平均 変動の標準偏差を $\sigma_{i}, \sigma_{j}$ とし, それらの共分散を $\sigma_{i j}$ とすると, この 2 地点の相関係数 $C_{i j}$ は式 (6) となる.

$$
C_{i j}=\frac{\sigma_{i j}}{\sigma_{i} \sigma_{j}}
$$

1994-1998 年の間に連続なデータのある計 56 地点で, 相関係数を求め, それを色分けした行列で表すことで 緯度による違いを示した。 


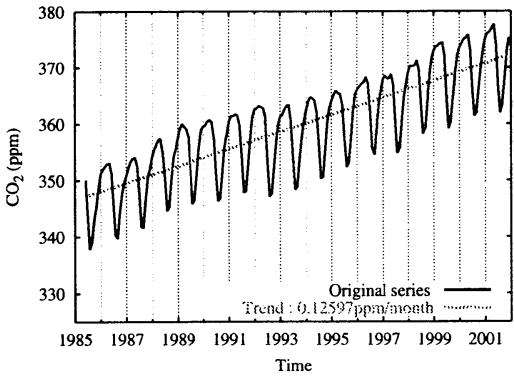

(a) Alert (Canada) $82^{\circ} 27^{\prime} \mathrm{N}$

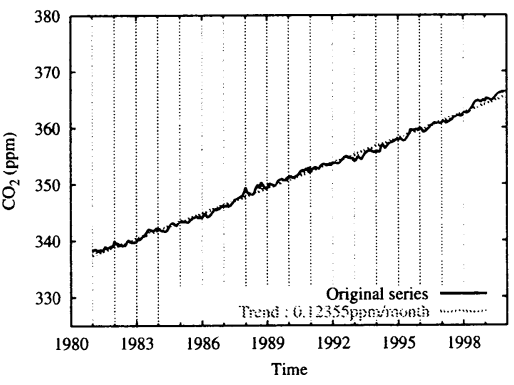

(b) Amsterdam Island (France) $37^{\circ} 48^{\prime} \mathrm{S}$

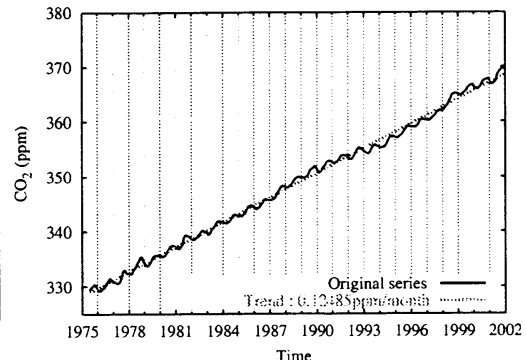

(c) South Pole (Antarctica) $89^{\circ} 59^{\prime} \mathrm{S}$

図-2 代表地点における $\mathrm{CO}_{2}$ 濃度の原系列（実線）及び傾向成分（破線）

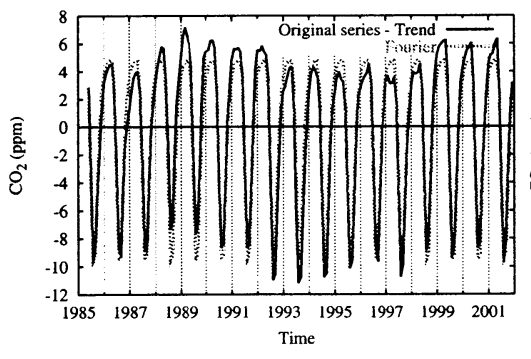

(a) Alert (Canada) $82^{\circ} 27^{\prime} \mathrm{N}$

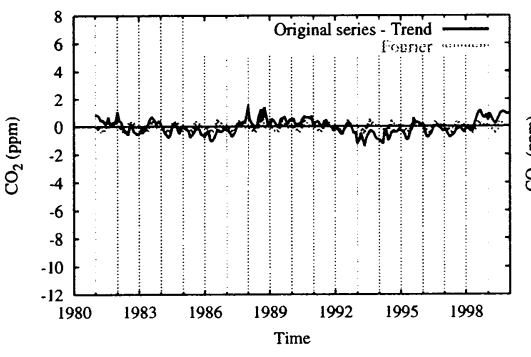

(b) Amsterdam Island (France) $37^{\circ} 48^{\prime} \mathrm{S}$

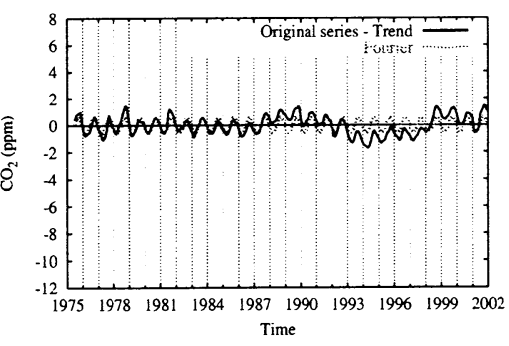

(c) South Pole (Antarctica) $89^{\circ} 59^{\prime} \mathrm{S}$

図-3 代表地点における $\mathrm{CO}_{2}$ 濃度の原系列から傾向成分を除いたもの（実線）と周期成分（破線）

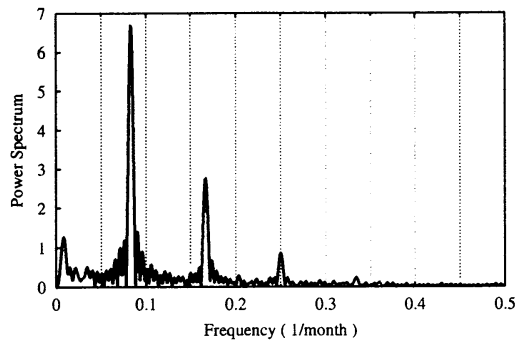

(a) Alert (Canada) $82^{\circ} 27^{\prime} \mathrm{N}$

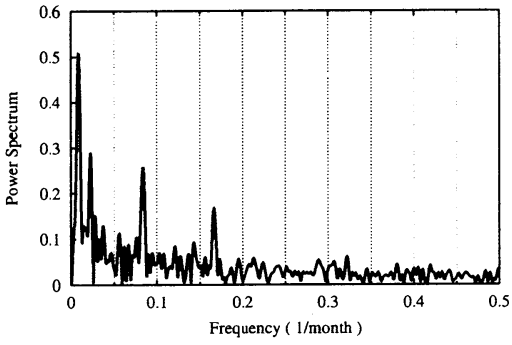

(b) Amsterdam Island (France) $37^{\circ} 48^{\prime} \mathrm{S}$

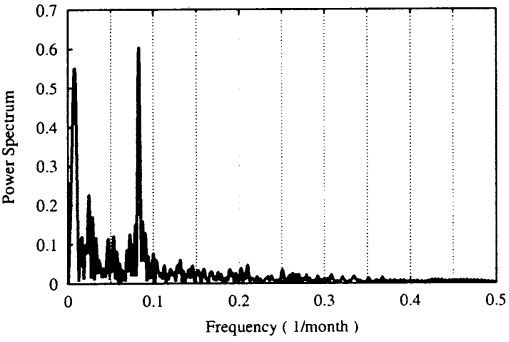

(c) South Pole (Antarctica) $89^{\circ} 59^{\prime} \mathrm{S}$

図-4 代表地点における $\mathrm{CO}_{2}$ 濃度の原系列から傾向成分を除いたもののスペクトル（縦軸スケールを合わせずに 卓越した周波数, スペクトル形状を見やすくしたもの）

\section{(5) $\mathrm{CO}_{2}$ 濃度空間分布図}

$\mathrm{CO}_{2}$ 濃度が世界全体でどのように変動しているのか を把握するために, Mobile データを除いた計 81 地点の 生データを用いて, 1997-2000 年において月毎に $\mathrm{CO}_{2}$ 濃度のコンター図を描いた。これにより，等高線の状 態や $\mathrm{CO}_{2}$ 濃度の高さ等を見ることで, $\mathrm{CO}_{2}$ 濃度の時空 間変動特性の把握を試みた。

\section{4. 解析結果および考察}

\section{（1）局所時間変動特性}

本論文では, 紙面の都合により, 変動特性の違いが 明らかな北半球の Alert, 南半球の Amsterdam Island, South Poleの 3 地点についての結果のみを載せた.

各解析地点での時系列解析を行った結果, 図-2 のよ うな長期的な増加傾向があることを確認できた. また 図-3より，原系列から傾向成分を除いたもの (実線)と
周期成分（点線）を比較すると, 特に図-3-b,cでずれ ている部分が確認でき, 明らかに 1 年以上の長期的な 周期を持っていると考えられる.

そこで, この長期的な周期を定量的に計るために，原 系列から傾向成分を除いたものを基にスペクトル解析 を行った結果が図-4である．この図から，やはり 1 年 周期が卓越していることが確認できる. その他にも, ス ペクル強度に多少の相違があるものの, ほとんどの地点 で約 10 年周期が検出された. これにより, 長期的な周 期とは約 10 年周期であることが確認できた. また図-5 から, 北半球における 1 年周期のスペクトル強度は, 約 10 年周期のスペクトル強度に比べ, 非常に強いことが 明らかである.

一方ある報告3)では, イベント（1991 年ピナツボ火 山噴火やエルニーニョ現象等）が, $\mathrm{CO}_{2}$ 濃度に影響を 与えているのではないかと言われており，このような理 由から, 約 10 年周期は見かけ上ではないかと考えられ ている，それを確認するために，図-6, 図-7のように 


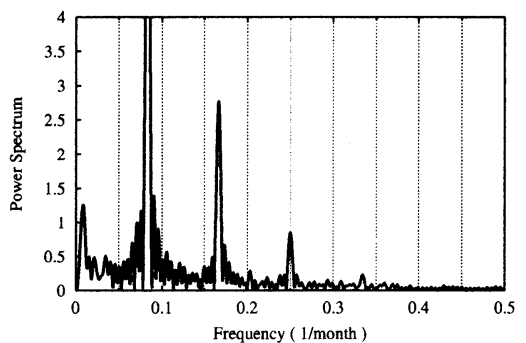

(a) Alert (Canada) $82^{\circ} 27^{\prime} \mathrm{N}$

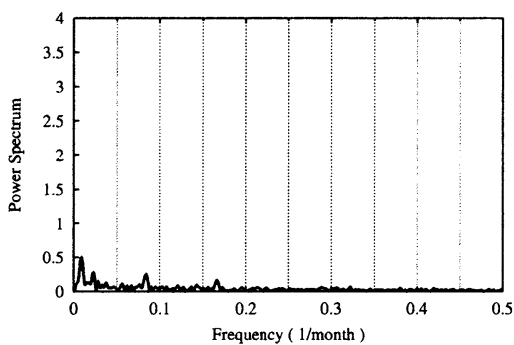

(b) Amsterdam Island (France) $37^{\circ} 48^{\prime} \mathrm{S}$

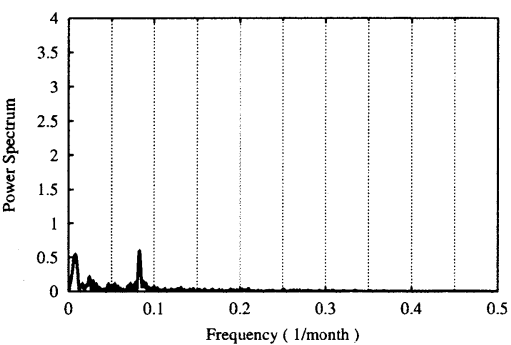

(c) South Pole (Antarctica) $89^{\circ} 59^{\prime} \mathrm{S}$

図-5 代表地点における $\mathrm{CO}_{2}$ 濃度の原系列から傾向成分を除いたもののスペクトル（繸軸スケールを合わせてス ペクトルの強さを比較したもの)

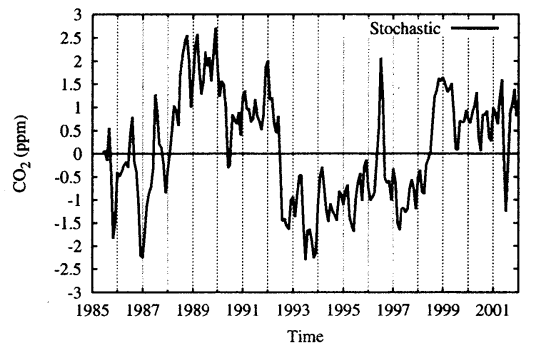

(a) Alert (Canada) $82^{\circ} 27^{\prime} \mathrm{N}$

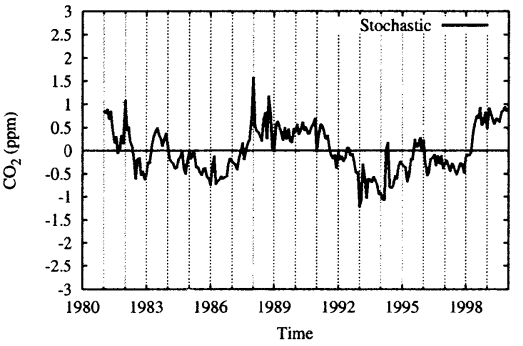

(b) Amsterdam Island (France) $37^{\circ} 48^{\prime} \mathrm{S}$

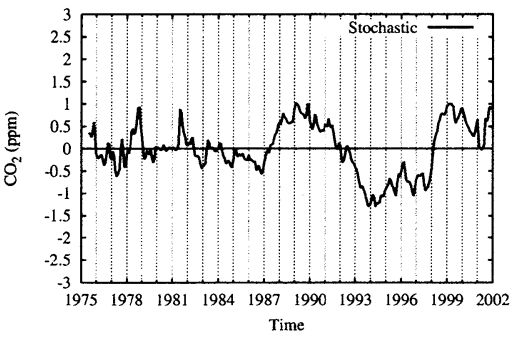

(c) South Pole (Antarctica) $89^{\circ} 59^{\prime} \mathrm{S}$

図-6 原系列から傾向成分と 1 年以下の周期成分を除いた成分（残差成分）の時系列図

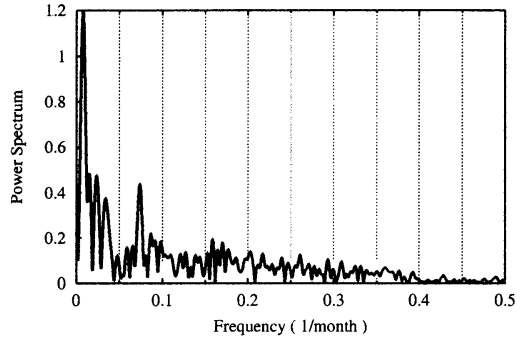

(a) Alert (Canada) $82^{\circ} 27^{\prime} \mathrm{N}$

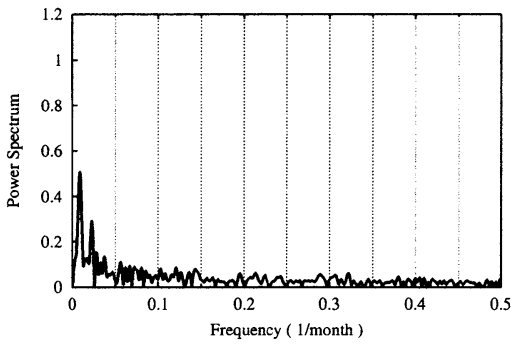

(b) Amsterdam Island (France) $37^{\circ} 48^{\prime} \mathrm{S}$

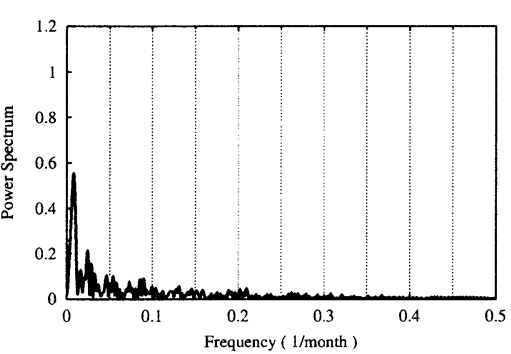

(c) South Pole (Antarctica) $89^{\circ} 59^{\prime} \mathrm{S}$

図-7 原系列から傾向成分と 1 年以下の周期成分を除いた成分（残差成分）のスペクル図

原系列から傾向成分と 1 年以下の周期成分を除いた成 分（残差成分）についてウェーブレット解析を行った. 連続ウェーブレット変換したものを 3 次元表示したも のを図-8に示し，それを真上から見たものを図-9に示 した. 連続ウェーブレット変換したものの約 10 年周期 に当る周波数成分（図-9 中に示す実線部）を取り出し たのが図-10であり, この周波数成分の振幅が時間変動 しているかどうかを確かめた，すると，ほとんどの地 点で振幅に時間変動があまり見られなかった，その反 面, South Pole（図-10-c）の他数地点では, 約 10 年 周期の周波数成分において急激な振幅の時間変動が見 られた. また, ピナツボ火山噴火の時期（1991 年 6 月） と重ねてみると, 約 10 年周期の周波数成分は 1991 年 6 月において既にピーク（1989 年 8,9 月頃）を過ぎ減 少傾向であることが確認でき, 約 10 年周期はピナツボ 火山噴火による見かけ上の周期とは言い難い結果であ ることが示された。これらの結果から, ピナツボ火山 噴火の影響による振幅の時間変動はあるかもしれない が, 約 10 年周期は実際に存在していると考えられる.

\section{（2）空間分布特性}

空間分布特性を把握するため, Mobile データを除い た計 81 地点の解析地点で解析を行った.

原系列から傾向成分を除いたものを基に求めたスペ クトルについて, 卓越した周波数別に区別し世界地図 上に分布させた結果が図-11-aである.これを見ると， 北半球では 1 年周期に依存した変動, 南半球では 1 年 周期は弱く約 10 年周期の影響を受けた変動をしており, 北半球と南半球とでは $\mathrm{CO}_{2}$ 濃度変動の主たる周期に違 いが明確に現れた。 また，卓越した周波数におけるス ペクトル強度のスケールを色で示した図-11-b を見て みると, 南半球と北半球におけるスペクトル強度の変 化の違いが明確である. 北半球では南下するにつれス ペクトル強度に顕著な弱化が見られ, スペクトル強度 が同程度な緯度帯がいくつか確認でき, 南半球では北 上してもスペクトル強度に減少があまり見られず, 南 半球全体で振幅が一定であることが明らかになった。

次に, 緯度順 (90Nから $90 \mathrm{~S}$ に向けて) に並べた解析 地点（計 56 地点）について各解析地点同士の 1994-1998 


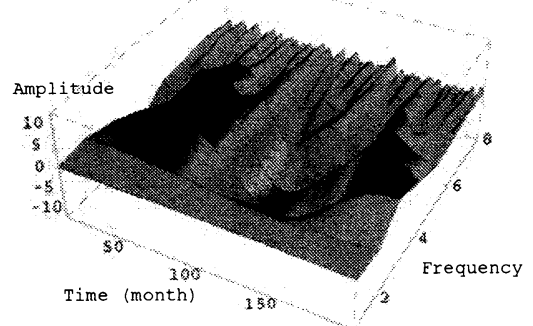

(a) Alert (Canada) $82^{\circ} 27^{\prime} \mathrm{N}$

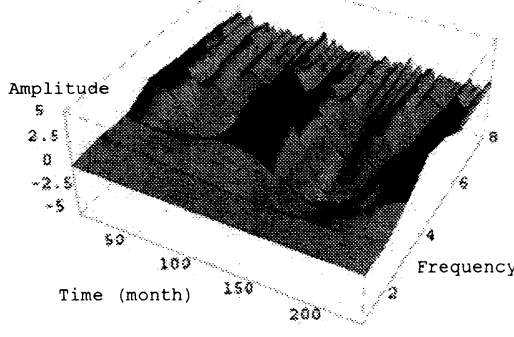

(b) AmsterdamIsland (France) $37^{\circ} 48^{\prime} \mathrm{S}$

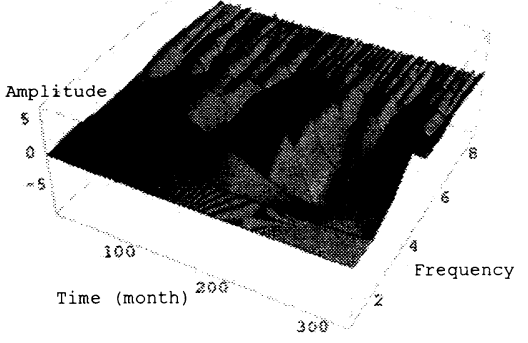

(c) South Pole (Antarctica) $89^{\circ} 59^{\prime} \mathrm{S}$

図-8 原系列から傾向成分と 1 年以下の周期成分を除いた成分（残差成分）の連続ウェーブレット変換 3 次元表示

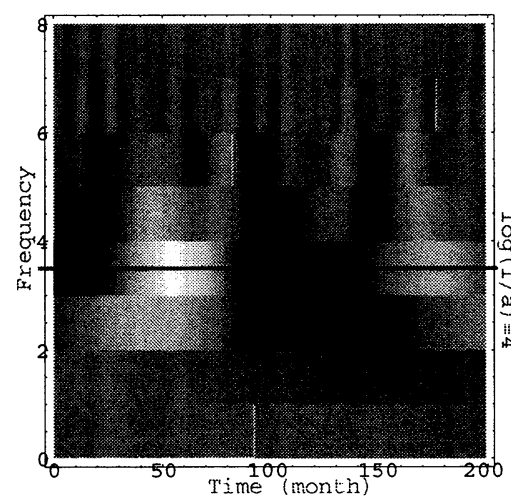

(a) Alert (Canada) $82^{\circ} 27^{\prime} \mathrm{N}$

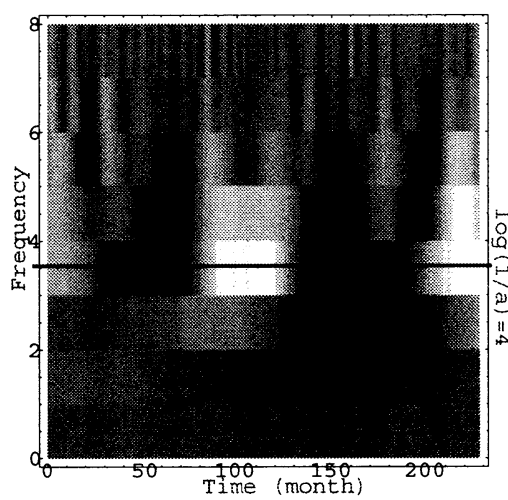

(b) AmsterdamIsland (France) $37^{\circ} 48^{\prime} \mathrm{S}$

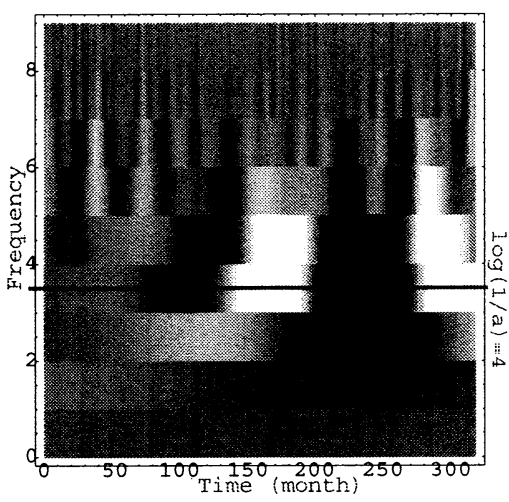

(c) South Pole (Antarctica) $89^{\circ} 59^{\prime} \mathrm{S}$

図-9 図-8 を真上から見た密度プロット図 *（残差成分） ※密度差（濃淡）が明確な周波数帯が卓越している.

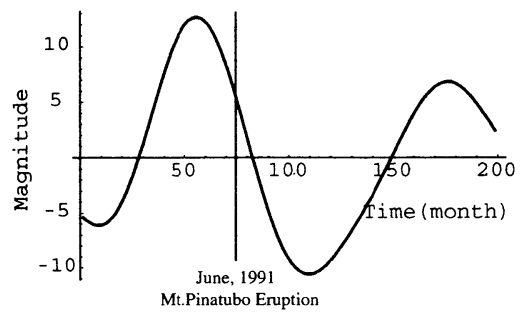

(a) Alert (Canada) $82^{\circ} 27^{\prime} \mathrm{N}$

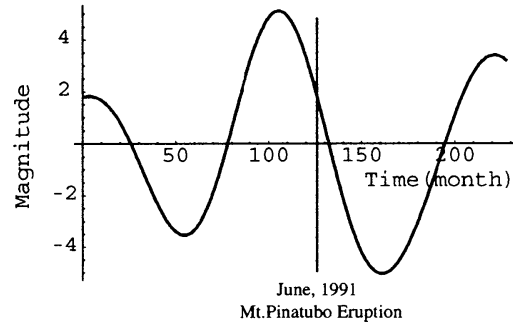

(b) AmsterdamIsland (France) $37^{\circ} 48^{\prime} \mathrm{S}$

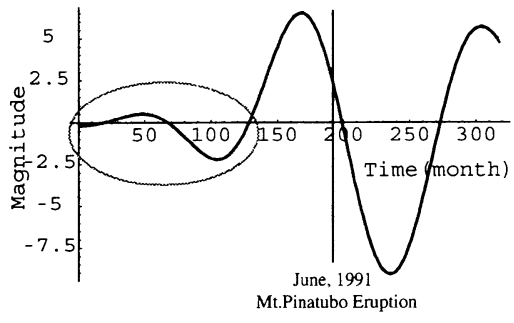

(c) South Pole (Antarctica) $89^{\circ} 59^{\prime} \mathrm{S}$

図-10 図-9における約 10 年周期の周波数成分（ $\log (1 / a)=4)$ を取り出したもの

年における相関係数を求め, 相関係数の值を色の濃淡 で表した相関行列を図-12 に示した。 その結果, $90 \mathrm{~N}$ $60 \mathrm{~N}, 30 \mathrm{~N}-\mathrm{EQ}, \mathrm{EQ}-90 \mathrm{~S}$ (南半球全体) で相関係数が高

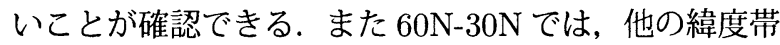
に比べ相関係数は低く，ばらつきが見られた。これは， $60 \mathrm{~N}-30 \mathrm{~N}$ (中緯度帯) では人間活動が活発であり, 中緯 度帯の解析地点毎の相関係数にばらつきが見られると 考えられる.ここで, 緯度帯別における地点数の違い が影響を与えていると考えられる点を注意しておく必 要がある.

\section{（3）時空間変動特性}

地球全体の時空間変動特性を把握することを目指し た. そのため, Mobileデータを除いた 81 地点のデータ を基に 1996-2000 年において月単位の $\mathrm{CO}_{2}$ 濃度時空間 分布図を描いた. 図-13 は, 全球規模における空間分布
図である．本論文では紙面の都合上，季節的な変動の 違いを明確に表している 1997 年の北半球における冬期 (1月)，春期 (4月)，夏期（8月）, 秋期（10月）の みを図-13に示した．等高線の引かれ方について見てみ ると, 北半球における冬から春にかけて（図-13-a,b) は緯度線に平行に引かれているが, 夏から秋にかけて （図-13-c,d）は等高線が乱れていることが確認できる. また, 北半球における秋から春にかけて（図-13-a,b,d） は, 北半球の方が南半球に比べ $\mathrm{CO}_{2}$ 濃度が高いことが 確認できる. しかし, 北半球における夏期（図-13-c） に限り, 北半球の方が南半球より $\mathrm{CO}_{2}$ 濃度が低くなっ ていることが確認できる.これは，北半球では，夏期 に排出量より吸収量が上回ることにより濃度が急激に 低下した結果であると考えられる．このように季節毎 に違う $\mathrm{CO}_{2}$ 濃度分布を示しているのは, 季節によって 植生の活性度が違うためだと考えられる。 


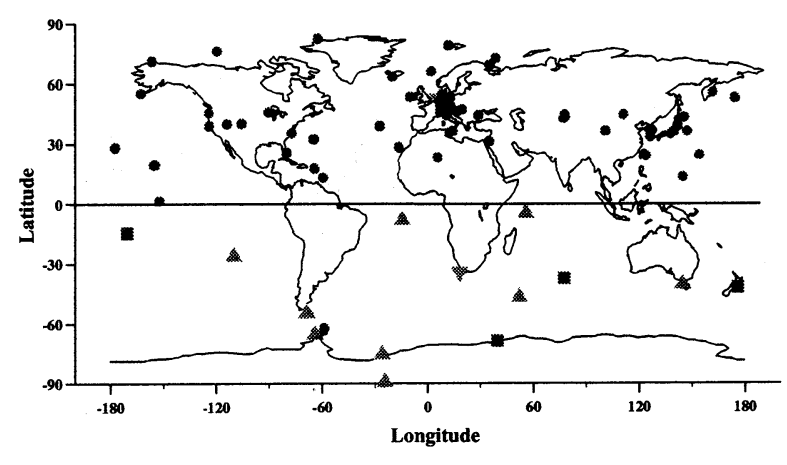

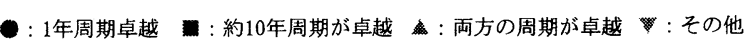
(a) 卓越した周波数の分布図

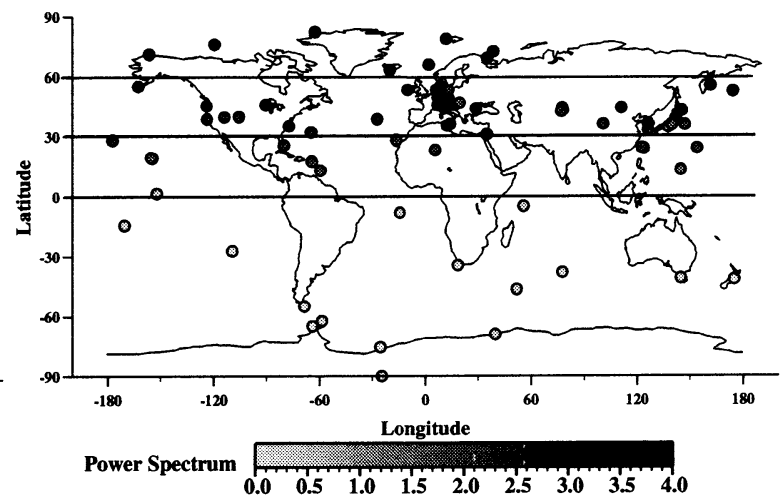

(b) 卓越した周波数におけるスペクトル強度分布図

図-11 地球全体における卓越周波数に関する分布図

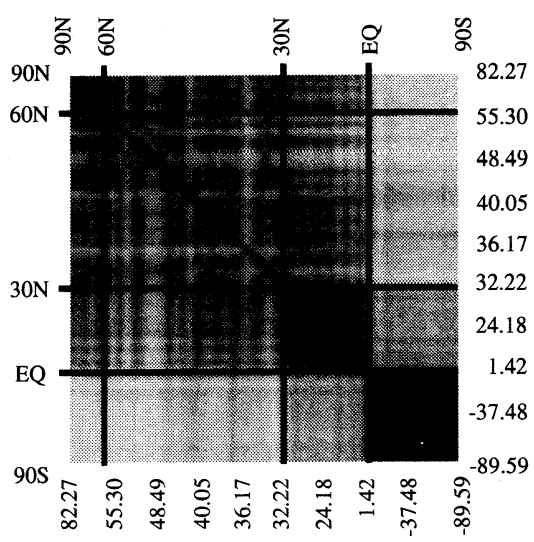

図-12 緯度順に並べた解析地点毎の相関行列

\section{5. まとめと今後の課題}

空間的分布特性として, 北半球では約 $30^{\circ}$ 毎, 南半 球では全体で, 相関係数の高い変動を示していることが 明らかになったことにより, 次のような緯度帯で $\mathrm{CO}_{2}$ 濃度変動特性を分類することができると考えられる. 北 半球高緯度帯 $(90 \mathrm{~N}-60 \mathrm{~N})$ では, 振幅の大きい 1 年周 期を主とした変動である. 北半球中緯度帯（60N-30N） では, 基本周期は 1 年であるものの人間活動の影響を強 く受けているために周期や振幅にばらつきを持った変 動である. 北半球低緯度帯 (30N-EQ) は, 1 年周期の 振幅が北半球高中緯度帯 $(90 \mathrm{~N}-30 \mathrm{~N})$ に比べ小さくな るため, 約 10 年周期の影響も受けた変動である. 南半 球では, 振幅の小さい約 10 年周期に依存した変動をし ており，イベントの影響を大きく受けると考えられる. 時空間変動特性として, 北半球における夏期（主に 8,9 月）に吸収が活発になることで, 南半球より北半 球の方が濃度が低くなること等, 季節毎の空間変動特 性を確認することができた.

本解析の結果により, 約 10 年周期はピナツボ火山噴 火の影響による見かけ上の周期とは言い難く, 約 10 年 周期は存在していると考えられる.

今後の課題として, その他のイベント（エルニーニョ
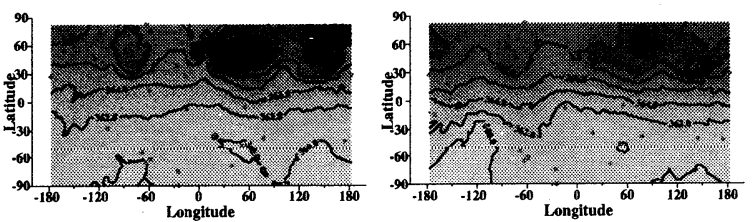

(a) January, 1997 (Winter)

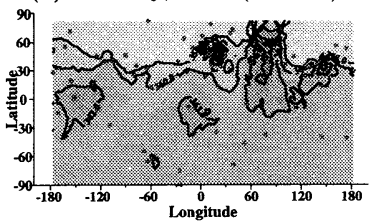

(c) August, 1997 (Summer)

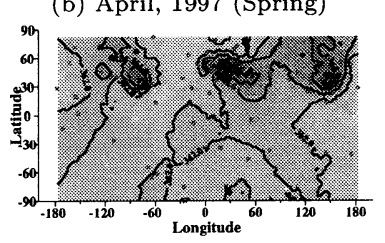

(b) Octorber, 1997 (Fall)

図-13 CO2 濃度時時空間分布図

やラニーニャ現象等）や時系列的な経済変動との関係 を考えることで, $\mathrm{CO}_{2}$ 濃度変動特性をより細かく把握 していく必要があると考えられる.

\section{参考文献}

1) IPCC: Climate Change 2001 : The Scientific Basis (Summary for Policymakers), Contribution of Working Group I to the Third Assessment Report of the IPCC, 2002

2) Kevin Robert Gurney et al. : TransCom $3 \mathrm{CO} 2$ inversion intercomparison: 1.Annual mean control results and sensitivity to transport and prior flux information, TELLUS, vol.55B, pp.555-579, 2003

3) Thomas J.Conway et al. : Evidence for interannual variability of the carbon cycle from the National Oceanic and Administration/ Climate Monitoring Oceanic and Diagnostics Laboratory Global Air Sampling Network, Jounal of geophysical research, vol.99, No.D11, pp.22831-22855, 1994

4) 斎藤兆古 : Mathematica によるウェーブレット変換, 朝 倉書店

(2003.9. 30 受付) 